\title{
Integrating diversity of smallholder coffee cropping systems in environmental analysis
}

\author{
Ivonne Acosta-Alba ${ }^{1,2,3,4}$ (D) Joachim Boissy ${ }^{5} \cdot$ Eduardo Chia $^{6} \cdot$ Nadine Andrieu $^{1,2,3}$
}

Received: 15 March 2019 / Accepted: 12 September 2019 / Published online: 24 October 2019

(C) The Author(s) 2019

\begin{abstract}
Purpose Coffee represents an important trade asset internationally. Around $70 \%$ of global coffee production is provided by 25 million smallholders farmers. In recent decades, coffee systems have been transformed into more intensified systems of coffee monoculture. The general objectives of this paper are to provide a better picture of the traditional coffee cropping systems and postharvest processes on-farm and to assess the environmental impacts, integrating the diversity of smallholder cropping systems.

Methods A Life Cycle Assessment from cradle to farm gate was performed for three cropping systems representative of Colombian coffee cultivation according to the associated crops and shadow trees: coffee alone (CA), coffee with transition shade (CTS), and coffee with permanent shade (CPS). The system studied includes inputs, agricultural production and postharvest operations using the wet method. The final product of farms is parchment bean coffee at farm gate. The technology used is representative of the average practices of smallholder coffee growers in the region. To address multiple functions of coffee, three functional units (FU) were selected: area by time (ha* $\mathrm{year}^{-1}$ unit area), productivity (ton of parchment coffee) and farmers income (1000 USD\$). Seven midpoint categories were selected: climate change, acidification, terrestrial eutrophication, freshwater eutrophication, marine eutrophication, freshwater ecotoxicity, and water resource depletion.

Results and discussion We present the life cycle inventory and impact assessment results from three types of cropping systems CA, CTS and CPS. For all FU, the CPS system has the lowest potential impact, excepted for marine eutrophication. CPS also has the highest coffee yields, however it has also the highest costs. Even if cropping system diversification is only one of multiple factors that influence environmental performance, agroforestry seems to be a promising path to reduce and mitigate environmental impacts by decreasing off-fam contributions (input fabrication).

Conclusions Results show the possibility that diversified cropping systems have an influence when assessing potential environmental impacts of coffee at farm gate and differences found might be influenced by shading in traditional coffee systems. Future work is needed to consider the real potential of CTS cropping system including land use and carbon dynamics. Assessments including social indicators and the rest of the value chain in particular coffee industrial transformation and utilization are also needed since the consumption stages are also a key driver to reduce the environmental footprint of coffee.
\end{abstract}

Keywords Coffee $\cdot$ Smallholders $\cdot$ Life cycle assessment $\cdot$ Associated crops $\cdot$ Shade management $\cdot$ Diversified cropping system $\cdot$ Agroforestry

Responsible editor: Thomas Jan Nemecek

Ivonne Acosta-Alba

ivonne_alba@orange.fr

1 UMR Innovation, French Agricultural Research Centre for International Development (CIRAD), 34398 Montpellier, France

2 International Center for Tropical Agriculture (CIAT), Km 17 Recta Cali-Palmira, Apartado Aéreo, 6713 Cali, Colombia
University of Montpellier, Montpellier, France

4 Evalivo, Sustainability Assessment of Food Systems, Saint Quentin, France

5 Agrotransfert Ressources et Territoires, 80200 Estrées-Mons, France

6 UMR Innovation, French National Institute for Agricultural Research, Campus Supagro Montpellier 2 place Viala, 34060 Montpellier Cedex 2, France 


\section{Introduction}

Coffee represents an important trade asset internationally (ICO 2018). Global coffee production represented in 2016 an area of almost 11 million hectares (10,975,184 ha) and a total production of 922,534 green coffee tons (FAO 2018). Waller et al. (2007) estimated that about 25 million farmers grow coffee and, according to Bacon (2005), approximately $70 \%$ of global production is provided by smallholders who are defined here as farmers operating on less than 2 ha (Lowder et al. 2016).

In recent decades, coffee cropping systems have been transformed into more intensified systems of coffee monoculture (Jezeer et al. 2017; Bhattarai et al. 2017). Single species cropping systems also might lead to important losses of biodiversity (Malézieux et al. 2009). Furthermore, coffee production deals with fluctuating market prices and with an increased vulnerability driven by climate change (Jezeer et al. 2017; Morton 2007). Expected effects for crops include phenological changes, modifications in pests and diseases, increased vulnerability of smallholders, and risk of loss of plant genetic resources (Ovalle-Rivera et al. 2015; Läderach et al. 2017).

Diversified coffee cropping systems with mixed species are linked with positive effects in terms of biodiversity protection (Buechley et al. 2015; Jha et al. 2014), carbon capture (van Rikxoort et al. 2014; Hergoualc'h et al. 2012), and oxygen generation (Pelupessy 2003). Diversified coffee cropping systems may also respond to food supply while the expected demand for food and convenience products continues to grow. Cropping systems diversity could be one possible path to reduce and mitigate environmental impacts which is poorly explored in environmental assessment.

Existing environmental studies on coffee crop production focus in particular on global warming impacts and carbon and energy footprints (De Beenhouwer et al. 2016; Hassard et al. 2014; Noponen et al. 2012; Ovalle-Rivera et al. 2015; van Rikxoort et al. 2014). Coffee production is not only leading to significant Climate Change (CC) impact but it is also suffering from it. A temperature increase of 2 degrees Celsius is expected by 2050 according to the climate change scenario A2 (IPCC 2000) and there are already visible consequences of 1 ${ }^{\circ} \mathrm{C}$ of global warming (IPCC 2018). Bunn et al. (2015) explored emissions scenarios where climate change reduces the global area suitable for coffee by about $50 \%$. Therefore, it is urgent to quantify the environmental impacts of coffee in order to find solutions to mitigate its impact while enhancing adaptation measures.

In literature, assessing other important impact categories than CC for coffee agricultural stage is still missing. Some integrated environmental assessments with life cycle assessment (LCA) of coffee exist in the literature (Büsser and Jungbluth 2009; Hanssen et al. 2007; Humbert et al. 2009). According to Bessou et al. (2013), who reviewed the main environmental impacts from perennial crops, attention should be paid to global warming, eutrophication, and toxicity issues. Acidification and water use are also important categories to assess for agricultural products (Notarnicola et al. 2017).

In available LCA coffee studies, few data from agricultural stages is presented. Only Coltro et al. (2006) provide data on agricultural stage with a clear life cycle inventory for Brazilian coffee. More recent coffee life cycle inventories (LCI) exist in LCA databases such as World Food LCA Database WFLCADB (Nemecek et al. 2015) and Agribalyse (Koch and Salou 2016) but unlike our study, LCI were not based on field surveys but on statistical data and literature references to represent an average production of the country for export. Besides, none of these studies explores clearly the difference between diversified coffee and monoculture cropping system management nor smallholder coffee production in particular.

The general objectives of this paper are (i) to provide a better picture of the life cycle inventory of coffee cropping systems and postharvest processes on farms of smallholders and (ii) to assess and quantify environmental impacts, integrating the diversity of cropping systems, which is poorly explored in LCA studies. Three functional units (FU) were selected to address the multifunctionality of agricultural systems. We carried out a LCA of coffee production in the Cauca region of Colombia.

After a presentation of the study site, goal and scope, the data inventory, and the models used to quantify emissions, we present and discuss the impact assessment results for seven impact categories of the three cropping systems representative of main coffee cropping systems found in Colombia (Arcila et al. 2007): coffee monoculture named coffee alone (CA), coffee with a transition crop during the early years of the coffee cycle called coffee with a transitional shade (CTS), and coffee with permanent shade (CPS).

\section{Methods}

\subsection{Site study and regional context}

Colombia has historically been an important producer and exporter of coffee and, despite several crises and losses of production, this country occupied the fourth position after Brazil, Vietnam, and Indonesia from 2006 to 2016 (FAO 2018). Colombian coffee production was around 852,000 tons in 2017 (FNCC 2017). The country has about 560,000 coffee growers, from which $95 \%$ are smallholder farmers with less than 2 ha, cultivating coffee on a production area of about 0.6 ha (Echevarria et al. 2015). The rise of coffee monoculture production that began in the 1960s as part of the green revolution (Forero 1996) probably contributed to environmental impacts increasing. 
The study was conducted in the rural northwest area of Popayán Municipality in Cauca Department in the Andean region in southwest Colombia $\left(76^{\circ} 40^{\prime} 58.1092^{\prime \prime} \mathrm{W}, 2^{\circ} 31^{\prime}\right.$ $\left.35.5288^{\prime \prime} \mathrm{N}\right)$ see Fig. 1. The Cauca Department is one important coffee production area of the country. In this area, farmers cultivate coffee and sugarcane however coffee production is the main agricultural activity.

The soils are sandy clay, sandy loam, and loam with organic matter levels between 1.30 and 11.57 units. The soils are rather acidic ( $\mathrm{pH} 3.71$ to 4.90 ). The average precipitation from 2011 to 2016 was $2460 \mathrm{~mm}$. The average humidity calculated from 1981 to 2010 by IDEAM (2018) is of $78 \%$ and the average temperature is $21.6{ }^{\circ} \mathrm{C}$ with a maximum temperature of $28.4{ }^{\circ} \mathrm{C}$ and a minimum of $17.3{ }^{\circ} \mathrm{C}$.

An increase in temperature is expected to affect the climatic suitability of crops, the climatic aptitude of crops tends to move toward higher zones (Jarvis et al. 2012). With no adaptation measures, $60 \%$ existing cultivation areas of $80 \%$ of Colombian crops might be affected (Ramirez-Villegas et al. 2012). Moreover, farmers are already facing abrupt environmental threats and changes. Major crises for Colombian coffee production from 2008 to 2011 were linked to epidemical issues of coffee rust which was partly caused by meteorological factors (e.g., a reduction in the diurnal thermal amplitude), and led to higher coffee vulnerability. This vulnerability, mixed with the increase in input costs, has resulted in low coffee profitability (Avelino et al. 2015).

Three cropping systems found in this area are representative of Colombian coffee cropping systems (Arcila et al. 2007).

- Coffee monoculture named coffee alone (CA)

- Coffee with a transition crop during the early years of the coffee cycle called coffee with a transitional shade (CTS) - Coffee with permanent shade (CPS).

In this area a previous works provided a database of 170 farms. ${ }^{1}$ Statistical analysis allowed to identify five farms types according to the nature of their coffee cropping systems (CA, CTS, CPS) and their livestock systems, these last one playing a key role in the fertilization of coffee cropping systems (Acosta-Alba et al. 2019).

- Crops and Husbandries - characterized by a larger area and a large number of animals (more than 30 heads) than other farm types. The coffee cropping system is exclusively CPS,

- Coffee Banana with no animal and coffee exclusively under CTS cropping system,

- Coffee Banana Transition with no animal and a mix of cropping systems: $30 \%$ of CA and $70 \%$ of CTS,

\footnotetext{
${ }^{1}$ The survey questionnaire and data are available at the following website: https://dataverse.harvard.edu/dataset.xhtml?persistentId=doi:10.7910/DVN/ 28324.
}

- Diversified Crops with 50\% CTS and 50\% CPS cropping systems and no animal,

- and Diversified Crops and Poultry with also 50\% of CTS and 50\% CPS cropping systems and some poultry.

\subsection{Goal and scope}

Coffee is the main activity for all farmers, who consider themselves traditional coffee growers. Coffee cropping systems are diverse as described before, therefore we wanted to compare cropping systems to assess the differences between them. The variability of factors affecting the environmental performance of farms is very large, being influenced by the composition of the soil, the relief of the planted area, the climatic conditions of each specific region, the varieties of coffee planted, the types of fertilizers and pesticides used, cropping management practices. In order to be able to capture cropping systems representative of the study area we first selected farms that were the most representative of the five main farm types (Acosta-Alba et al. 2019). Thirteen farms were surveyed (2 to 3 per farm type). Since in a same farm type there are different coffee cropping systems, in total, 20 cropping system were sampled and their technical management described: three CA, nine CTS and eight CPS. This survey confirmed the similarities of technical management of each cropping system, consequently, one representative cropping system was chosen to be assessed by a midpoint LCA.

Seven midpoint categories were selected: climate change, acidification, terrestrial eutrophication, freshwater eutrophication, marine eutrophication, freshwater ecotoxicity, and water resource depletion.

All of the processes, from cradle to the farm gate, were assessed. Postharvest operations, which take place on-farm, were included. Figure 2 synthesizes the processes considered and the system boundaries. The system studied includes inputs, agricultural production (including main crop, associated crops and shadow tress) and postharvest operations. The final product of farms is parchment bean coffee, produced with a constant humidity degree in the area between $10 \%$ and $12 \%$, at farm gate.

The temporal scale included the whole crop cycle. As recommended by Bessou et al. (2013), the non-productive periods (nursery and the first year and a half of plantation) were taken into account for the LCA and also for the calculation of average yields. Associated or transitional crops, when existing, were also considered. No allocation was done since these associated or transitional crops are only grown with coffee, have no particular agronomic management and no specific data was available.

According to farmers in the region, coffee crop and associated crops fulfil multiple functions: contribute to agricultural land use, food production and the provision of high-quality traditional coffee which generate revenue (Acosta-Alba et al. 


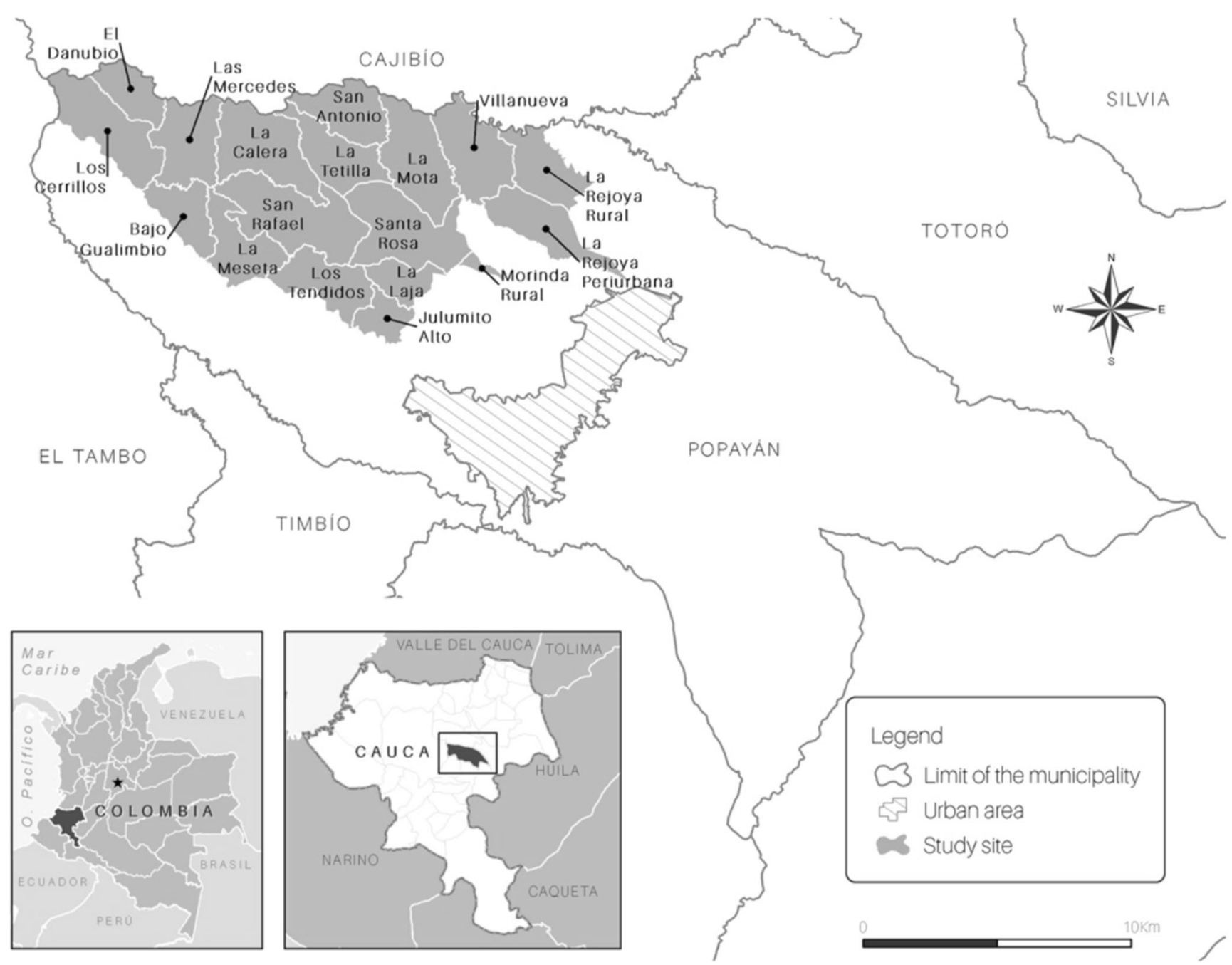

Fig. 1 Map of the site study. Northwest area of Popayán Municipality in Cauca Department in the Andean region in southwest Colombia (coordinates $76^{\circ} 40^{\prime} 58.1092^{\prime \prime}$ W. $2^{\circ} 31^{\prime} 35.5288^{\prime \prime}$ N). Farms surveyed are located in the dark grey zone

2019). Three functional units (FU) were selected to address the multifunctionality of agricultural systems (Nemecek et al. 2016; Nemecek et al. 2011). The first FU was expressed in unit of area (ha*year ${ }^{-1}$ unit area) to include the perennial nature of this cropping system. The second FU was expressed in ton of parchment coffee, and the third one considered farmer income (1000 USD\$). The last two FU were selected to include economic wealth creation and quality expectations. The technology used in farms is representative of the average practices of smallholder coffee growers in the region. The stages assessed are described in detail in the next section.

\subsection{Data for life cycle inventory and emissions}

The primary data for the inventory were obtained during surveys and visits to farms. Farmers follow the recommendations for fertilization after soil analysis. The background processes used were selected from the Ecoinvent database v.3.2 (Wernet et al. 2016).

\subsubsection{Agricultural production}

The crop cycle is composed of non-productive and productive stages. Coffee plants are produced on-farm. The coffee crop has a 6 or 7-year cycle, after which it is cut down to the stump. The coffee plant remains on the plot for two to three cycles before being replanted. There are two manual harvests per year in the productive stages. After harvest, red coffee beans are prepared using the wet method: the pulp and mucilage are removed after fermentation and the product washed. The coffee beans are dried in plastic greenhouses using heat from solar energy. The product at the farm gate is parchment coffee. Most production and postharvest operations are done manually.

The non-productive stage begins in the nursery garden, where coffee is grown from seed by farmers. All the processes are manual; no machine is used. Varieties of Arabica coffee used by farmers are Colombia, Castillo, Caturra, and Supremo. When the seedlings reach the "matchstick" stage, 


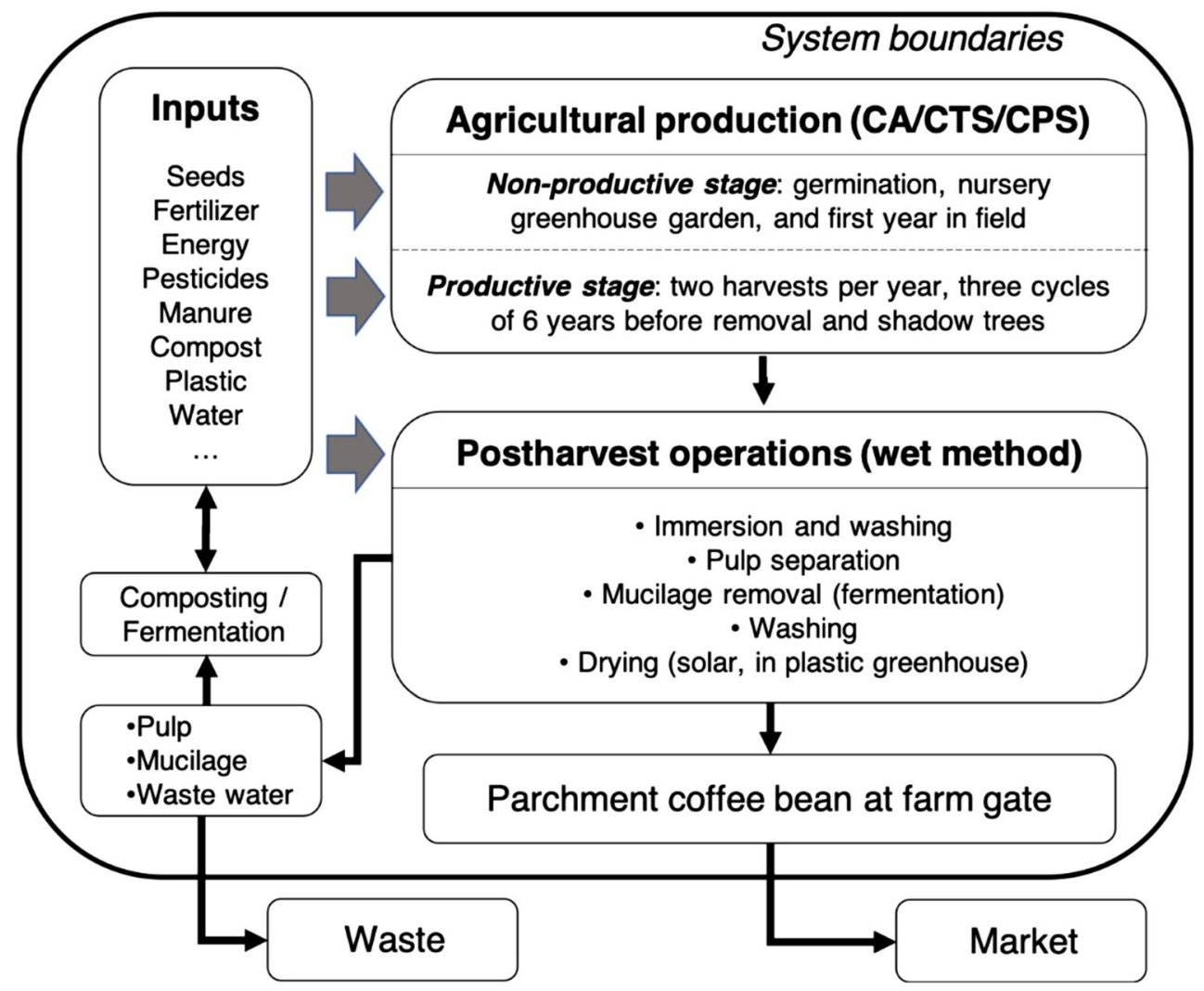

Fig. 2 System boundaries and stages assessed. The system studied includes inputs. Agricultural production with non-productive and productive years. Shadow trees species and associated crops in field were

selected ones are planted in bags. At 3 months, fertilizer is applied. Weeds are removed regularly by hand. The field is prepared and, according to the cropping system, shade trees are established. The density of coffee trees is 5000 per hectare. At planting, according to soil and crop needs, compost or fertilizers are used plus dolomite a month after.

In CTS cropping system, coffee is associated with plantain (Musa sp.), which is frequently used as a transition crop. It is usually produced in the first half of the coffee crop cycle. Plantain grows between the rows, with a density of 50 to 150 plants per hectare. It is an important product for food security in the region. In CPS, coffee is associated with Inga sp. trees, with a density of 78 trees per hectare. Inga is not consumed. There is no particular management for these associated crops but residues were included to calculate emissions.

Compost is used in the nursery process. It is produced by farmers using fermented coffee pulp and manure. The compost process is entirely manual, without the use of either energy or any specific material. When there is no husbandry on the farm, the manure is purchased. If husbandry exists on farms, producers might use compost also in productive years of coffee.

The productive stage of coffee requires nutrition and fertilizer management as well as disease and pest control. Arabica included when present. The compost produced in farm from coffee residues and postharvest operations using the wet method are also comprised. The final product of farms is parchment bean coffee at farm gate.

coffee is usually grown as a single stem system. Pruning and grass management are done manually, sometimes using a small-motor scythe three times per year. The average use is around 6.251 of diesel per hectare per run. There are two harvesting periods and they require salaried workers.

\subsubsection{Postharvest operations}

Postharvest operations are similar for all types of farm. The coffee beans are processed the same day as harvested. The processing method is called a full-wash process. The skin of the cherry is removed using a pulper machine and water. The second layer of pulp or sugar coating, the mucilage, is removed after fermentation. The coffee is then washed and dried with solar energy inside homemade plastic greenhouses. For the values of water used for coffee washing and wet processes, famers gave an estimated consumption since no water meter records exist. Water use was about $10 \mathrm{l}$ per $\mathrm{kg}$ of parchment coffee. This quantity is close to 9.21 (or $11.41 / \mathrm{kg}$ of greenbean coffee), a value from literature (Coltro et al. 2006). Data for diesel and electricity values for postharvest operations were found in Coltro et al. (2006).

Emissions to air, fresh and marine water and soil were calculated using models presented on Table 1. Emissions from 
Table 1 List of emissions calculated to air, fresh and marine water and soil and models used

\begin{tabular}{|c|c|}
\hline List of emissions & Model - methodology \\
\hline \multicolumn{2}{|l|}{ To air } \\
\hline Ammonia & $\begin{array}{l}\text { Direct due to fertilization EMEP/CORINAIR (EEA } \\
\text { 2013) Tier2 }\end{array}$ \\
\hline Dinitrogen monoxide & Direct due to fertilization - IPCC (2006) Tier 1 \\
\hline Dinitrogen monoxide & $\begin{array}{l}\text { Indirect from volatilisation and leaching - (IPCC 2006) } \\
\text { Tier } 1\end{array}$ \\
\hline Nitrogen oxide & $\begin{array}{l}\text { Direct due to fertilization EMEP/CORINAIR (EEA } \\
\text { 2013) Tier2 }\end{array}$ \\
\hline Carbon dioxide, fossil & Direct from lime use - (IPCC 2006) Tier 1 \\
\hline \multicolumn{2}{|l|}{ To water } \\
\hline \multicolumn{2}{|l|}{ Groundwater } \\
\hline Phosphate & Leaching. WFLDB (2014) from Prasuhn (2006) \\
\hline Nitrate & $\begin{array}{l}\text { SQCB model WFLDB (2014) from Faist Emmenegger } \\
\text { et al. (2009) }\end{array}$ \\
\hline \multicolumn{2}{|l|}{ Surface water } \\
\hline Phosphate & Erosion runoff. WFLDB (2014) from Prasuhn (2006) \\
\hline Phosphorus & WFLDB (2014) from Prasuhn (2006) \\
\hline \multicolumn{2}{|l|}{ To soil } \\
\hline Pesticides & Nemecek and Schnetzer (2011) \\
\hline $\begin{array}{l}\text { Cadmium, Copper, Zinc, Lead, Nickel, Chromium, } \\
\text { Mercury }\end{array}$ & SALCA model from Freiermuth (2006) \\
\hline
\end{tabular}

crop residues of coffee, associated crops and shadow trees in the field were included in the calculations. Values were found in the literature: from van Rikxoort et al. (2014) for coffee, for plantain from Tock et al. (2010), and for Inga sp. from Leblanc et al. (2005, 2007). The yield for plantain was estimated at $2.47 \mathrm{t}^{*} \mathrm{ha}^{-1}$ with 150 plants per hectare. The yield for Inga sp. was valued around $8.5 \mathrm{t}^{*} \mathrm{ha}^{-1}$ with 78 trees per hectare.

\subsection{Life cycle impact assessment models}

We used the models and assessment methods recommended in the ILCD 2011 report (EC-JRC 2011). Seven midpoint categories were selected to represent most of the main impact categories in agriculture (Notarnicola et al. 2017): climate change, acidification, terrestrial eutrophication, freshwater eutrophication, marine eutrophication, freshwater ecotoxicity, and water resource depletion. The software used was SimaPro version 8.4 (Pré Consultants).

\section{Results}

\subsection{Life cycle inventory}

Table 2 presents the main inputs used in agricultural and postharvest processes. It shows that for the non-productive phase, the three coffee cropping systems used compost which is produced on farms by fermentation of coffee pulp (nitrogen content $4.2 \%$ ) and animal manure (in the case of poultry the nitrogen content is around $8 \%$ ).

For Mineral fertilizers used (N, P, K formula), nitrogen was the element commonly used to reason soil amendment. For the productive phase, inputs of $\mathrm{N}, \mathrm{P}, \mathrm{K}$ were higher for the $\mathrm{CTS}$ and lower for CPS. Inputs of $\mathrm{CaCO}_{3}$ (soil acidity correctives) were higher for CPS. CPS was the only cropping system that used compost in productive phase. Considering that nitrogen dynamics in soils from organic and mineral are different, to give an idea of the nitrogen level of inputs, we estimated that compost represents $25 \mathrm{~kg}$ of nitrogen per year and the Inga $s p$. nitrogen fixation including nitrogen from residues, represents around $48 \mathrm{~kg}$ of $\mathrm{N}$ per hectare. Thus, total nitrogen inputs in CPS were around $226 \mathrm{~kg}$ of $\mathrm{N}$ per productive year per hectare. In the post-harvest phase, inputs of diesel, electricity and water were higher for the CPS which obtained the better yield of parchment coffee.

Table 3 shows the inventory of calculated emissions in field, including the values of direct and indirect emissions from agricultural operations and management per cropping system. Estimated emissions of non-productive years were close between three cropping systems excepting for carbon dioxide where no correctives were applied (CTS). During productive years, emissions of ammonia and dinitrogen monoxide emissions were lower for CPS given the lower amounts of nitrogen used. In contrast, the lowest nitrogen emissions to water came from the CTS cropping system, followed by CPS 
Table 2 Inventory of coffee production per hectare according to cropping systems: coffee alone (CA), coffee transition shade (CTS), and coffee permanent shade (CPS). The table summarize the inputs used in the three steps of production: nonproductive stage (nursery), the productive stage and post harvests processes. Parameters are presented by hectare and the yield is expressed in parchment coffee

\begin{tabular}{|c|c|c|c|c|}
\hline Parameters & Unit & CA & CTS & CPS \\
\hline \multicolumn{5}{|l|}{ Non-productive stage } \\
\hline \multicolumn{5}{|l|}{ Fertilizers } \\
\hline Compost* & $\mathrm{t}^{*} \mathrm{ha}^{-1}$ & 7.5 & 5.0 & 5.0 \\
\hline $\mathrm{N}$ & $\mathrm{kgN}^{*} \mathrm{ha}^{-1}$ & 100 & 108 & 105 \\
\hline $\mathrm{P}$ & $\mathrm{kgP} * \mathrm{ha}^{-1}$ & 16 & 27 & 25 \\
\hline K & $\mathrm{kgK}^{*} \mathrm{ha}^{-1}$ & 96 & 108 & 102.5 \\
\hline \multicolumn{5}{|l|}{ Correctives } \\
\hline $\mathrm{CaCO}_{3}$ & $\mathrm{~kg}^{*} \mathrm{ha}^{-1}$ & 150 & 0 & 500 \\
\hline \multicolumn{5}{|l|}{ Productive stage } \\
\hline \multicolumn{5}{|l|}{ Pesticides } \\
\hline Insecticides - Chlorpyrifos (active matter) & $\mathrm{kg}^{*} \mathrm{ha}^{-1}$ & & 0.6 & \\
\hline \multicolumn{5}{|l|}{ Fertilizers } \\
\hline $\mathrm{N}$ & $\mathrm{kgN} * \mathrm{ha}^{-1}$ & 312.5 & 306 & 153 \\
\hline $\mathrm{P}$ & $\mathrm{kgP}^{2} \mathrm{ha}^{-1}$ & 50 & 108 & 54 \\
\hline K & $\mathrm{kgK} * \mathrm{ha}^{-1}$ & 300 & 324 & 162 \\
\hline Compost* & $\mathrm{t} * \mathrm{ha}^{-1}$ & & & 5 \\
\hline \multicolumn{5}{|l|}{ Correctives } \\
\hline $\mathrm{CaCO}_{3}$ & $\mathrm{~kg}^{*} \mathrm{ha}^{-1}$ & 75 & 300 & 250 \\
\hline \multicolumn{5}{|l|}{ Energy } \\
\hline Diesel (weeding and cutting coffee) & $1 * \mathrm{ha}^{-1}$ & 15.75 & 15.75 & 15.75 \\
\hline \multicolumn{5}{|l|}{ Postharvest } \\
\hline Diesel & $1 * \mathrm{ha}^{-1}$ & 15,000 & 19,000 & 21,000 \\
\hline Electricity & $\mathrm{kWh}^{*} \mathrm{ha}^{-1}$ & 330 & 413 & 468 \\
\hline Water used & $\mathrm{m}^{3} * \mathrm{ha}^{-1}$ & 15.00 & 18.75 & 21.25 \\
\hline \multicolumn{5}{|l|}{ Products } \\
\hline Parchment coffee & $\mathrm{t}^{*} \mathrm{ha}^{-1}$ & 1.5 & 1.9 & 2.1 \\
\hline
\end{tabular}

*Compost produced on-farm and CA. The lower nitrate emissions were due to soil characteristics, including differences in clay content and organic matter levels.

\subsection{Impact assessment}

Table 4 presents the results for the three coffee cropping systems, the three FU, and for the seven midpoint categories selected: Climate change (CC), acidification (Aci), terrestrial eutrophication (TEU), freshwater eutrophication (FwEU), marine eutrophication (MarEU), freshwater ecotoxicity (FwEtox) and water resource depletion (WRD). Results are shown in tables from a whole crop cycle. Non-productive stages represent around $10 \%$ of TEU, FwEU and MarEU; $9 \%$ of FwEtox, $7 \%$ of WDR, and $6 \%$ of CC.

For non-productive and productive stages and for all functional units, the CPS permanent shade cropping system had the lowest potential impact, except for MarEU impact category. On the opposite, CA cropping system had the highest impacts for all FU, excepted for FwEtox and WRD by hectare*year ${ }^{-1}$. CTS had the highest impact for FwEtox for all FU and for WRD per hectare*year ${ }^{-1}$. For CC, Aci, TEU, FwEU and WRD the results of CA and CTS are close by hectare but higher differences appeared by ton of parchment coffee.

We compared cropping systems for each FU using normalized results based on the maximum impact per impact category, per FU and cropping system in Table 5. The higher result per category and per FU was attributed the maximum (100\%) and others results were pondered to contrast the three cropping systems. For all FU and all impact categories, CPS and CTS had an average of $34 \%$ less potential impact than CA. By ton of parchment coffee, the average difference was about $34 \%$. By 1000 USD\$ of income, the mean value reduction was estimated to $43 \%$. By hectare*year, the reduction was limited and about $17 \%$.

A first contribution analysis for the whole cycle (non-productive and productive years), was made between in-field, offfarm and post-harvest processes by cropping coffee cropping system for the seven impacts categories (Fig. 3). In field processes include crop management operations and direct emissions. Processes contributing to "In-field" potential impacts were grouped in emissions from inputs application, diesel 
Table 3 Inventory of calculated emissions by coffee cropping system (coffee alone, CA; coffee transition shade, CTS; and coffee permanent shade, CPS) for nonproductive $(\mathrm{Np})$ and productive (P) stages

\begin{tabular}{|c|c|c|c|c|c|c|c|}
\hline \multirow[t]{2}{*}{ Emissions } & \multirow[t]{2}{*}{ Unit } & \multicolumn{2}{|l|}{$\mathbf{C A}$} & \multicolumn{2}{|l|}{ CTS } & \multicolumn{2}{|l|}{ CPS } \\
\hline & & $\mathbf{N p}$ & $\mathbf{P}$ & $\mathrm{Np}$ & $\mathbf{P}$ & Np & $\mathbf{P}$ \\
\hline \multicolumn{8}{|l|}{ To air } \\
\hline Ammonia & $\mathrm{kg}^{*} \mathrm{ha}$ & 4.69 & 11.38 & 4.63 & 11.14 & 4.52 & 6.20 \\
\hline Direct Dinitrogen monoxide & $\mathrm{kg} * \mathrm{ha}$ & 2.15 & 6.54 & 2.44 & 6.64 & 2.81 & 5.23 \\
\hline Indirect Dinitrogen monoxide & $\mathrm{kg} * \mathrm{ha}$ & 0.59 & 1.74 & 0.66 & 1.75 & 0.74 & 1.32 \\
\hline Nitrogen oxide & $\mathrm{kg} * \mathrm{ha}$ & 6.56 & 16.88 & 6.58 & 16.53 & 6.42 & 9.01 \\
\hline Carbon dioxide, fossil & $\mathrm{kg}^{*} \mathrm{ha}$ & 66 & 33 & 0 & 132 & 220 & 110 \\
\hline \multicolumn{8}{|l|}{ To water } \\
\hline \multicolumn{8}{|l|}{ Groundwater } \\
\hline Phosphate & $\mathrm{kg} * \mathrm{ha}$ & 0.12 & 0.23 & 0.12 & 0.23 & 0.10 & 1.15 \\
\hline Nitrate & $\mathrm{kg} * \mathrm{ha}$ & 2039 & 3513 & 303 & 517 & 2617 & 3281 \\
\hline \multicolumn{8}{|l|}{ Surface water } \\
\hline Phosphate & $\mathrm{kg} * \mathrm{ha}$ & 0.63 & 1.61 & 0.67 & 1.58 & 0.46 & 0.87 \\
\hline Phosphorus & $\mathrm{kg} * \mathrm{ha}$ & 1.98 & 1.98 & 1.98 & 1.98 & 1.49 & 1.49 \\
\hline \multicolumn{8}{|l|}{ To soil } \\
\hline Chlorpyrifos & $\mathrm{kg} * \mathrm{ha}$ & & & & 0.60 & & \\
\hline Cadmium & $\mathrm{g} * \mathrm{ha}$ & 0.03 & 0.07 & 0.02 & 0.10 & 0.08 & 0.06 \\
\hline Copper & $\mathrm{g} * \mathrm{ha}$ & 2.82 & 7.24 & 2.39 & 7.99 & 4.32 & 4.39 \\
\hline Zinc & $\mathrm{g} * \mathrm{ha}$ & 13.3 & 38.5 & 13.9 & 39.5 & 16.7 & 20.5 \\
\hline Lead & $\mathrm{g} * \mathrm{ha}$ & 1.07 & 1.94 & 0.57 & 2.71 & 2.35 & 1.71 \\
\hline Nickel & $\mathrm{g} * \mathrm{ha}$ & 3.53 & 6.26 & 1.84 & 8.89 & 7.88 & 5.65 \\
\hline Chromium & $\mathrm{g} * \mathrm{ha}$ & 47.8 & 25.9 & 0.81 & 96.5 & 157.7 & 79.6 \\
\hline Mercury & $\mathrm{g} * \mathrm{ha} * 10^{-6}$ & 6.23 & 0 & 4.15 & 0 & 4.15 & 4.15 \\
\hline
\end{tabular}

used for grass management and pruning, and home-made compost use. Off-farm operations refer to input fabrication (pesticides, mineral fertilizers and soil acidity correctives) and transportation processes. "Post-harvest" processes include energy used to transform coffee cherry to coffee bean (electricity and diesel used in machines) as water used for depulping coffee.

The profile between cropping systems showed an important contribution of in-field emissions for Aci, TEU, FwEU and more than $90 \%$ of potential MarEU. Off-farm processes had the heavier potential impacts on WRD for all cropping systems, contributing from $7 \%$ to $58 \%$ for the rest of impact categories. Postharvest stages contributed around $11 \%$ to $47 \%$ to all impact categories excepting MarEU. For FwEtox, results varied according to cropping systems: in CA, the most important contributors were Off-farm processes, in CTS main impact came from in-field processes and in CPS from postharvest activities.

A second more detailed contribution analysis (Fig. 4) showed that the critical points to be improved for each

Table 4 Results for midpoint impact categories assessed for coffee cropping systems (coffee alone, CA; coffee transition shade, CTS; and coffee permanent shade, CPS) using three functional units: ton of parchment coffee per hectare year ${ }^{-1}$, and per USD $\$ 1000$ of income

\begin{tabular}{|c|c|c|c|c|c|c|c|c|c|c|}
\hline \multirow[t]{2}{*}{ Impact category } & \multirow[t]{2}{*}{ Units } & \multicolumn{3}{|c|}{ per ton of parchment coffee } & \multicolumn{3}{|c|}{ per hectare year ${ }^{-1}$} & \multicolumn{3}{|c|}{ per 1000USD $\$$ of income } \\
\hline & & CA & CTS & CPS & $\mathbf{C A}$ & CTS & CPS & CA & CTS & CPS \\
\hline Climate change (CC) & $\mathrm{t} \mathrm{CO}_{2}$ eq & 5.8 & 4.6 & 3.1 & 8.7 & 8.7 & 6.4 & 3.5 & 2.6 & 1.5 \\
\hline Acidification (Aci) & molc $\mathrm{H}+\mathrm{eq}$ & 63.9 & 49.5 & 35.7 & 96 & 94 & 74.9 & 39 & 28 & 17 \\
\hline Terrestrial eutrophication (TEU) & molc $\mathrm{N}$ eq & 254 & 195 & 141 & 382 & 371 & 296 & 156 & 110 & 68 \\
\hline Freshwater eutrophication (FwEU) & $\mathrm{kg} P$ eq & 2.7 & 2.0 & 1.4 & 4.1 & 3.8 & 3.0 & 1.7 & 1.1 & 0.7 \\
\hline Marine eutrophication (MarEU) & $\mathrm{t} \mathrm{N}$ eq & 0.5 & 0.1 & 0.3 & 0.79 & 0.13 & 0.7 & 0.32 & 0.04 & 0.17 \\
\hline Freshwater ecotoxicity (FwEtox) & CTU e $10^{4}$ & 3.6 & 6.3 & 2.0 & 5.4 & 11.9 & 4.2 & 2.2 & 3.5 & 1.0 \\
\hline Water resource depletion (WRD) & $\mathrm{m}^{3}$ water eq & 46.7 & 38.8 & 22.1 & 70.1 & 73.8 & 46.4 & 28.7 & 21.9 & 10.6 \\
\hline
\end{tabular}


Table 5 Comparison between cropping systems for all functional units. The higher result per category and per FU was attributed the maximum $(100 \%)$ and others results were pondered to contrast three cropping systems (coffee alone, CA; coffee transition shade, CTS; and coffee permanent shade, CPS)

\begin{tabular}{|c|c|c|c|c|}
\hline Impact category & Cropping coffee system & FU (ton) & FU (ha*yr) & FU 1000USD\$ \\
\hline \multirow[t]{3}{*}{ Climate change } & CA & $100 \%$ & $100 \%$ & $100 \%$ \\
\hline & CTS & $79 \%$ & $100 \%$ & $73 \%$ \\
\hline & CPS & $53 \%$ & $74 \%$ & $41 \%$ \\
\hline \multirow[t]{3}{*}{ Acidification } & CA & $100 \%$ & $100 \%$ & $100 \%$ \\
\hline & CTS & $77 \%$ & $98 \%$ & $71 \%$ \\
\hline & CPS & $56 \%$ & $78 \%$ & $43 \%$ \\
\hline \multirow[t]{3}{*}{ Terrestrial eutrophication } & CA & $100 \%$ & $100 \%$ & $100 \%$ \\
\hline & CTS & $77 \%$ & $97 \%$ & $70 \%$ \\
\hline & CPS & $56 \%$ & $76 \%$ & $43 \%$ \\
\hline \multirow[t]{3}{*}{ Freshwater eutrophication } & CA & $100 \%$ & $100 \%$ & $100 \%$ \\
\hline & CTS & $73 \%$ & $93 \%$ & $67 \%$ \\
\hline & CPS & $52 \%$ & $73 \%$ & $41 \%$ \\
\hline \multirow[t]{3}{*}{ Marine eutrophication } & CA & $100 \%$ & $100 \%$ & $100 \%$ \\
\hline & CTS & $13 \%$ & $17 \%$ & $12 \%$ \\
\hline & CPS & $67 \%$ & $93 \%$ & $52 \%$ \\
\hline \multirow[t]{3}{*}{ Freshwater ecotoxicity } & $\mathrm{CA}$ & $58 \%$ & $46 \%$ & $63 \%$ \\
\hline & CTS & $100 \%$ & $100 \%$ & $100 \%$ \\
\hline & CPS & $32 \%$ & $36 \%$ & $27 \%$ \\
\hline \multirow[t]{3}{*}{ Water resource depletion } & $\mathrm{CA}$ & $100 \%$ & $95 \%$ & $100 \%$ \\
\hline & CTS & $83 \%$ & $100 \%$ & $76 \%$ \\
\hline & CPS & $47 \%$ & $63 \%$ & $37 \%$ \\
\hline
\end{tabular}

type of process. In-field emissions from inputs had the heavier impact between $3 \%$ to $99 \%$ for all cropping systems in comparison to grass management, compost use and pesticides. The higher contribution of "Off-farm" processes came from nitrogen fertilizers (up to 40\%) for all categories excepting MarEU. In Post-harvest, the use of diesel for depulping machines was the process that contributed the more from $1 \%$ up to $36 \%$.

\section{Discussion}

\subsection{What is the environmental impact of the different coffee cropping systems?}

CPS cropping system had the lowest impact all FU considered, except for marine eutrophication. The nitrogen fixed by Inga sp. and the nitrogen from tree residues were included in the calculation of total nitrogen input (Leblanc et al. 2005, 2007). The permanent shade cropping system (CPS) also had the highest coffee yields, which seems surprising especially since in the literature, the permanent shade coffee is often related to a yield decrease (van Rikxoort et al. 2014, Farfán-Valencia 2005). However, Villarreyna Acuña (2016) explains that controlled shade might have a positive effect on productivity. Other authors have found that high densities of shade trees can have an adverse effect on coffee yields, particularly in zones of optimal conditions of soil fertility, radiation, and water (Da Matta 2004; Wang et al. 2015), whereas Soto Pinto et al. (Soto-Pinto et al. 2000) showed that it is shade cover percentage rather than shade tree density that affects yields. On the farms visited, shade tree densities were rather small (150 plantain plants and 78 Inga sp. trees) compared with those found in the literature: 193 to 305 trees for van Rikxoort et al. (2014) for farms in Mexico, Guatemala, Nicaragua, El Salvador, and 278 platain trees in Colombia (Farfán-Valencia 2014).

CTS cropping system had the lowest values for marine eutrophication. The latter impact category expresses the degree of emitted nutrients reaching marine end compartments and nitrogen is considered as a limiting factor in marine water (EC-JRC 2011). An important part of the nitrogen used by Musa sp. comes out of the field with the fruits since these plants are not fertilized and play an important role in the region's food security. Probably, this causes a deficit of nitrogen that can affect the yield of coffee when no specific management of transition crops is applied.

In the CTS cropping system, freshwater ecotoxicity was also higher than in other cropping systems. In CTS, insecticide was used to control leafcutter ants (Atta sp.). The products applied lead to important ecotoxicity impacts. This is an important issue in the region. In the other cropping systems, home-produced biological control (such as urine) were used although they seem to have only fairly limited success according to farmers. Most of the farmers visited did not consider 
a) $\mathrm{CA}$

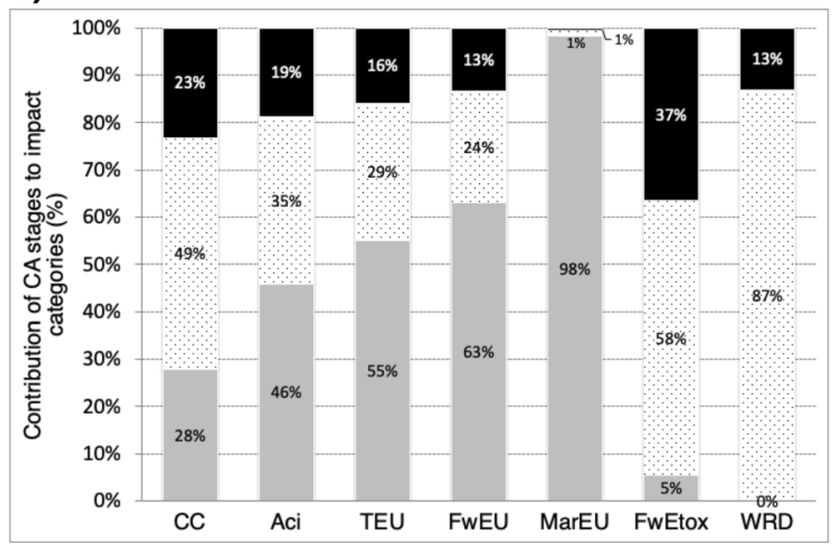

\section{b) CTS}

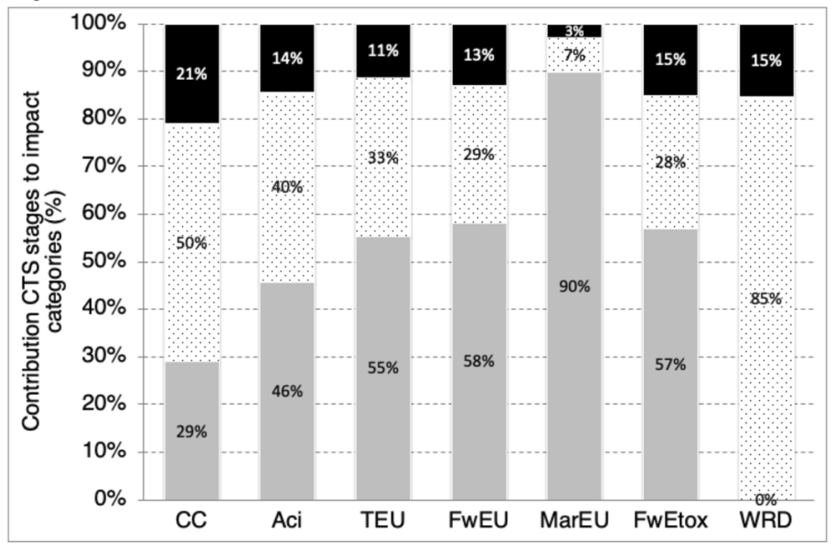

\section{c) CPS}

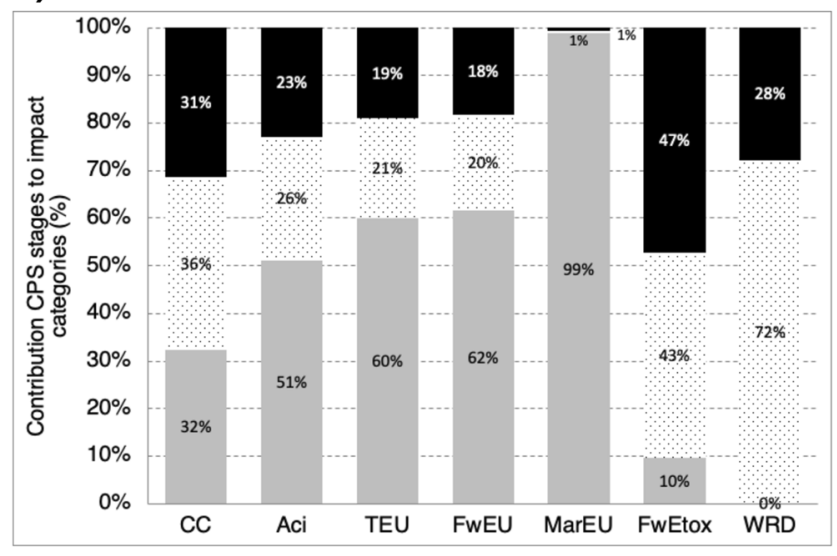

In field

\section{Off-farm}

Postharvest

Fig. 3 Relative contribution analysis by cropping coffee system. Results for climate change (CC), acidification (Aci), terrestrial eutrophication (TEU), freshwater eutrophication (FwEU), marine eutrophication (MarEU), freshwater ecotoxicity (FwEtox), and water resource depletion (WRD) are given for the three coffee cropping systems $a$. for Coffee Alone (CA), $b$. for Coffee Transition Shade (CTS) and $c$. for Coffee Permanent Shade (CPS). Potential impacts are grouped by in field. Off-farm. and postharvest processes insecticides as an input since they use these products only in small quantities and not systematically. Arzoumanidis et al. (2017) found similar results regarding the importance of freshwater ecotoxicity of agricultural production stage and freshwater eutrophication compared to the rest of the stages of an LCA of roasted coffee.

Differences between the management of cropping systems might be explained beyond soil properties (rather acid with high content of organic matter). In the CPS cropping system, several factors interact with nitrogen soil dynamics and nitrogen availability, here we explored the permanent shade and a higher level of compost used. Inga sp. fixes nitrogen and its production remains in the field, which reduces the need for external nitrogen inputs. In addition, it is the only cropping system in which large amounts of manure for compost were available (husbandry exists on the farm), so the amount of chemical fertilizer used was almost half as important as in other cropping systems. Even if a fraction of the nitrogen fixed is leached with a fraction of the nitrogen applied by fertilizers, the avoided emissions of input fabrication substantially reduce the potential impact in most of the categories. Authors have noted considerable gaps in the literature's knowledge since the 1990s regarding the decomposition of organic residues and the interactions between mineral and organic amendments (Szott and Kass 1993). Annual crops appear to be probably less nutrient-efficient and sustainable than systems based on perennial crops and agroforestry, but it is difficult to generalize and separate the factors of the system's overall performance.

Off-farm processes made up almost $80 \%$ of the contribution of water resource depletion for the three cropping systems. For climate change, off-farm represents from $36 \%$ to $50 \%$ of total emissions and corresponds to the orders of magnitude in the literature (van Rikxoort et al. 2014). Thus, the replacement of chemical fertilizers by compost, for example, possibly supports a reduction in potential impacts assessed.

Postharvest processes made a non-negligible contribution to all categories ( $13 \%$ to $47 \%$ ) excepting MarEU. Even if traditional systems studied in Colombia use wet processes to wash and depulp coffee berries (Oliveros et al. 2013), dry processes are not recommended because of the negative impacts on quality (Puerta Quintero 1996). Other more ecological processes have been promoted, such as Becolsub and Ecomill technology that reduces water use by about $95 \%$, but the costs are a barrier for adoption by smallholders (Cenicafé 2018; Sanz Uribe et al. 2011). Recent estimations showed that this technology is used on around $30 \%$ of coffee processing plants (Cenicafé 2018). Currently, there is no treatment for recycling of water and only a part of the coffee pulp is composted for nursery. A better optimization of postharvest and recycling processes might reduce the impacts of coffee production. However, attention must be paid to methane emissions from composting and fermentation in water waste management, especially in regions where sedimentation ponds are used with poor management (Ruben et al. 2018). 
a

\begin{tabular}{|c|c|c|c|c|c|c|c|c|c|c|c|}
\hline CA & \multicolumn{3}{|c|}{ In-field } & \multicolumn{5}{|c|}{ Off-farm } & \multicolumn{3}{|c|}{ Postharvest } \\
\hline \multirow{2}{*}{ Impact Category } & \multirow{2}{*}{$\begin{array}{c}\text { In-field } \\
\text { emissions }\end{array}$} & \multirow{2}{*}{$\begin{array}{c}\text { Grass } \\
\text { management } \\
\text { (Diesel) }\end{array}$} & \multirow{2}{*}{ Compost } & \multirow{2}{*}{ Pesticides } & \multicolumn{3}{|c|}{ Mineral fertilizers } & \multirow{2}{*}{ Correctives } & \multirow{2}{*}{$\begin{array}{c}\text { Diesel } \\
\text { (Depulping) }\end{array}$} & \multirow{2}{*}{$\begin{array}{c}\text { Electricity } \\
\text { (Depulping) }\end{array}$} & \multirow{2}{*}{$\begin{array}{l}\text { Washing } \\
\text { water }\end{array}$} \\
\hline & & & & & $\mathrm{N}$ & $\mathrm{P}$ & $\mathrm{K}$ & & & & \\
\hline Climate change $(\mathrm{CC})$ & $26 \%$ & $2 \%$ & $0 \%$ & $0 \%$ & $40 \%$ & $1 \%$ & $7 \%$ & $1 \%$ & $22 \%$ & $2 \%$ & - \\
\hline Acidification (Aci) & $45 \%$ & $1 \%$ & $0 \%$ & $0 \%$ & $25 \%$ & $1 \%$ & $8 \%$ & $1 \%$ & $15 \%$ & $4 \%$ & - \\
\hline Terrestrial eutrophication (TEU) & $54 \%$ & $1 \%$ & $0 \%$ & $0 \%$ & $20 \%$ & $1 \%$ & $7 \%$ & $1 \%$ & $12 \%$ & $4 \%$ & - \\
\hline Freshwater eutrophication (FwEU) & $62 \%$ & $1 \%$ & $0 \%$ & $0 \%$ & $17 \%$ & $3 \%$ & $3 \%$ & $1 \%$ & $12 \%$ & $1 \%$ & - \\
\hline Marine eutrophication (MarEU) & $98 \%$ & $0 \%$ & $0 \%$ & $0 \%$ & $1 \%$ & $0 \%$ & $0 \%$ & $0 \%$ & $1 \%$ & $0 \%$ & - \\
\hline Freshwater ecotoxicity (FwEtox) & $3 \%$ & $2 \%$ & $0 \%$ & $0 \%$ & $43 \%$ & $3 \%$ & $9 \%$ & $3 \%$ & $28 \%$ & $8 \%$ & - \\
\hline Water resource depletion (WRD) & & $0 \%$ & $0 \%$ & $0 \%$ & $47 \%$ & $2 \%$ & $38 \%$ & $0 \%$ & $0 \%$ & $0 \%$ & $13 \%$ \\
\hline
\end{tabular}

b

\begin{tabular}{|c|c|c|c|c|c|c|c|c|c|c|c|}
\hline \multirow{3}{*}{ Impact Category } & \multicolumn{3}{|c|}{ In-field } & \multicolumn{5}{|c|}{ Off-farm } & \multicolumn{3}{|c|}{ Postharvest } \\
\hline & \multirow{2}{*}{$\begin{array}{l}\text { In-field } \\
\text { emissions }\end{array}$} & \multirow{2}{*}{$\begin{array}{c}\text { Grass } \\
\text { management } \\
\text { (Diesel) }\end{array}$} & \multirow{2}{*}{ Compost } & \multirow{2}{*}{ Pesticides } & \multicolumn{3}{|c|}{ Mineral fertilizers } & \multirow{2}{*}{ Correctives } & \multirow{2}{*}{$\begin{array}{c}\text { Diesel } \\
\text { (Depulping) }\end{array}$} & \multirow{2}{*}{$\begin{array}{c}\text { Electricity } \\
\text { (Depulping) }\end{array}$} & \multirow{2}{*}{$\begin{array}{c}\text { Washing } \\
\text { water }\end{array}$} \\
\hline & & & & & $\mathrm{N}$ & $P$ & $\mathrm{~K}$ & & & & \\
\hline Climate change $(\mathrm{CC})$ & $27 \%$ & $1 \%$ & $0 \%$ & $0 \%$ & $38 \%$ & $2 \%$ & $9 \%$ & $0 \%$ & $20 \%$ & $1 \%$ & - \\
\hline Acidification (Aci) & $45 \%$ & $1 \%$ & $0 \%$ & $0 \%$ & $25 \%$ & $3 \%$ & $9 \%$ & $3 \%$ & $14 \%$ & $1 \%$ & - \\
\hline Terrestrial eutrophication (TEU) & $55 \%$ & $1 \%$ & $0 \%$ & $0 \%$ & $20 \%$ & $1 \%$ & $9 \%$ & $3 \%$ & $11 \%$ & $0 \%$ & - \\
\hline Freshwater eutrophication (FwEU) & $57 \%$ & $1 \%$ & $0 \%$ & $0 \%$ & $17 \%$ & $6 \%$ & $5 \%$ & $0 \%$ & $12 \%$ & $1 \%$ & - \\
\hline Marine eutrophication (MarEU) & $90 \%$ & $0 \%$ & $0 \%$ & $0 \%$ & $4 \%$ & $0 \%$ & $3 \%$ & $0 \%$ & $3 \%$ & $0 \%$ & - \\
\hline Freshwater ecotoxicity (FwEtox) & $56 \%$ & $1 \%$ & $0 \%$ & $0 \%$ & $19 \%$ & $3 \%$ & $5 \%$ & $0 \%$ & $12 \%$ & $3 \%$ & - \\
\hline Water resource depletion (WRD) & & $0 \%$ & $0 \%$ & $0 \%$ & $42 \%$ & $3 \%$ & $39 \%$ & $0 \%$ & $0 \%$ & $0 \%$ & $15 \%$ \\
\hline
\end{tabular}

c

\begin{tabular}{|c|c|c|c|c|c|c|c|c|c|c|c|}
\hline CPS & \multicolumn{3}{|c|}{ In-field } & \multicolumn{5}{|c|}{ Off-farm } & \multicolumn{3}{|c|}{ Postharvest } \\
\hline \multirow{2}{*}{ Impact Category } & \multirow{2}{*}{$\begin{array}{c}\text { In-field } \\
\text { emissions }\end{array}$} & \multirow{2}{*}{$\begin{array}{c}\text { Grass } \\
\text { management } \\
\text { (Diesel) }\end{array}$} & \multirow{2}{*}{ Compost } & \multirow{2}{*}{ Pesticides } & \multicolumn{3}{|c|}{ Mineral fertilizers } & \multirow{2}{*}{ Correctives } & \multirow{2}{*}{$\begin{array}{c}\text { Diesel } \\
\text { (Depulping) }\end{array}$} & \multirow{2}{*}{$\begin{array}{c}\text { Electricity } \\
\text { (Depulping) }\end{array}$} & \multirow{2}{*}{$\begin{array}{l}\text { Washing } \\
\text { water }\end{array}$} \\
\hline & & & & & $\mathrm{N}$ & $\mathrm{P}$ & K & & & & \\
\hline Climate change $(\mathrm{CC})$ & $30 \%$ & $2 \%$ & $0 \%$ & $0 \%$ & $28 \%$ & $2 \%$ & $5 \%$ & $1 \%$ & $29 \%$ & $2 \%$ & - \\
\hline Acidification (Aci) & $33 \%$ & $1 \%$ & $17 \%$ & $0 \%$ & $17 \%$ & $2 \%$ & $5 \%$ & $2 \%$ & $22 \%$ & $1 \%$ & - \\
\hline Terrestrial eutrophication (TEU) & $40 \%$ & $1 \%$ & $19 \%$ & $0 \%$ & $14 \%$ & $1 \%$ & $5 \%$ & $1 \%$ & $18 \%$ & $0 \%$ & - \\
\hline Freshwater eutrophication (FwEU) & $61 \%$ & $1 \%$ & $0 \%$ & $0 \%$ & $12 \%$ & $4 \%$ & $3 \%$ & $1 \%$ & $17 \%$ & $2 \%$ & - \\
\hline Marine eutrophication (MarEU) & $99 \%$ & $0 \%$ & $0 \%$ & $0 \%$ & $0 \%$ & $0 \%$ & $0 \%$ & $0 \%$ & $1 \%$ & $0 \%$ & - \\
\hline Freshwater ecotoxicity (FwEtox) & $7 \%$ & $2 \%$ & $0 \%$ & $0 \%$ & $29 \%$ & $5 \%$ & $7 \%$ & $3 \%$ & $36 \%$ & $11 \%$ & - \\
\hline Water resource depletion (WRD) & & $0 \%$ & $0 \%$ & $0 \%$ & $37 \%$ & $3 \%$ & $33 \%$ & $0 \%$ & $0 \%$ & $0 \%$ & $27 \%$ \\
\hline
\end{tabular}

Fig. 4 Detailed contribution analysis by each step for CA, CTS and CPS cropping coffee systems. Results of impact assessment are given for seven impact categories: climate change (CC), acidification (Aci), terrestrial eutrophication (TEU), freshwater eutrophication (FwEU), marine eutrophication (MarEU), freshwater ecotoxicity (FwEtox), and water resource depletion (WRD). In-field impacts contributors are infield emissions of inputs application, diesel used for grass management and cutting coffee and home-made compost use, Off-farm shows impacts of fabrication of each type of input (pesticides, mineral fertilizers and soil acidity correctives). Post harvest processes include energy used to transform coffee cherry to coffee bean (electricity and diesel used in machines) as water used for depulping. Results are presented in $a$. for Coffee Alone (CA), in $b$. for Coffee Transition Shade (CTS) and in $c$. for Coffee Permanent Shade (CPS)
The detailed contribution analysis showed the critical points where efforts might be prioritized for each cropping system. For CA and CTS reducing the amount of mineral fertilizers, might have a double positive effect in reducing the environmental impact in-field and off-farm. For CPS were compost had already replaced mineral fertilizers, a more efficient technology for depulping and a better control of emissions from compost use could be explored. Also trade-off between acidification and terrestrial eutrophication exists and have to be considered whether promoting compost (Acosta-Alba et al. 2019).

As Coltro et al. (2006) showed, input reduction is "the first principle for sustainability of any process". Like these authors, we also found a wide variability of the amount of inputs used (fertilizers and pesticides) and yield between cropping systems. Values of three coffee cropping systems assessed range with average values presented in their study (Coltro et al. 2006) which sampling included family farms to thousand hectares company farms. Even if multiple factors (climate, soils, geographic and varieties among others) might explain these differences, they show also large possibilities to improve environmental efficiency.

The transition from one cropping system to another is also a possible path to reduce environmental impact of coffee production. As presented in section 2.1, in three of the five types of farms existing in the region, at least two different cropping systems co-exist in the same farm. During surveys, farmers declared to be increasingly interested in agroforestry, changing from coffee alone cropping systems to temporary and permanent shade cropping systems and swapping to coffee varieties adapted to shade. Farmers are also progressively using higher quantities of organic manure and producing 
compost or other forms of home-made amendments as bokashi (Quiroz and Céspedes 2019). These transformations are being rapidly spreading in the region but they are constrained by manure availability in particular for farms with no livestock.

\subsection{What are the strengths and drawbacks of the methodology?}

Splitting the effect that might have each practice on environmental performance of agricultural systems seems unlikely with a small sample in a single study. However, compared to purely statistical data analysis, the in-depth study of systems based on detailed surveys helped to capture the consistency of producers' technical choices who consider their farms and cropping systems as a whole. The selection of farms for our study was based on a broader typology of farms what gives some genericity to our results in the study site.

Our results were in the range of results found by other authors for the agricultural stage per ton of parchment coffee, the emissions from cropping systems $\left(\mathrm{CA}=5.8 \mathrm{t} \mathrm{CO}_{2}\right.$ eq, $\mathrm{CTS}=$ $4.6 \mathrm{t} \mathrm{CO}_{2}$ eq, and $\mathrm{CPS}=3.1 \mathrm{t} \mathrm{CO}_{2}$ eq) (De Beenhouwer et al. 2016; Hassard et al. 2014; Noponen et al. 2012; Ovalle-Rivera et al. 2015; van Rikxoort et al. 2014). After the conversion of coffee cherries to parchment coffee equivalent, our results were in the range of the Noponen et al. (2012) carbon footprint study of organic coffee.

Most of the existing studies focus on the carbon footprint, greenhouse gas emissions, and energy resource depletion. We chose to go beyond the potential impact of climate change and to include other impact categories associated with the agricultural stage of perennial cropping systems (Bessou et al. 2013; Notarnicola et al. 2017): global warming, eutrophication (terrestrial, marine, and freshwater), toxicity (freshwater ecotoxicity), acidification, and water use. Such a comprehensive analysis, quantifying and comparing environmental impacts, allows us to strengthen the existing literature aiming to characterize the difference between shaded and non-shaded coffee cropping systems (Da Matta 2004; Soto-Pinto et al. 2000; Meylan et al. 2017; Sauvadet et al. 2019). We showed the added value of coffee cropping system with permanent shade to address different environmental concerns, provided agronomic practices are improved such as management of compost. However, management changes have to be carefully studied before being applied since, for coffee as for other perennial crops and agroforestry systems, the adaptation and expected response to an external change is less flexible than for annual crops and these decisions have implications for several years (Läderach et al. 2017).

Using multiple functional units helped representing the multifunctionality of agricultural systems (Nemecek et al. 2011). In the case study, there was no significant differences between systems following FU. Indeed, some small changes between CA and CTS appeared with hectare*year FU for climate change and water depletion, but raw results did not present a very significant difference. Using gross margin as FU instead of income and including allocation of associated crops are also interesting perspectives for future work.

Even if the models used were not specifically developed for a tropical climate, already we can have an idea of which are the other impact categories to be aware of. Land use and land transformation are important impact categories in tropical contexts but the data needed for calculations were not available (Koch and Salou 2016; Koellner et al. 2013). On the farms visited, there was no clear historical record of crops and previous land use, but no forest had been replaced at least in the last 20 years. Little information is also available about carbon stocks in soil for a perennial crop such as coffee.

\section{Conclusions}

The promotion of monoculture coffee was generally made under the assumption of higher yields permitted by higher coffee density and less incidence of some pests and diseases. But, this assumption was made underestimating the diverse environmental impacts of such cropping systems. Coffee Alone is usually considered as the representative coffee cropping system due to the high productivity and the adoption of this coffee system by bigger farms. However, most of coffee is produced by smallholders and the diversity of systems might represent also a high diversity of potential impact values. Results showed the possibility that diversified cropping systems have an influence when assessing potential environmental impacts of coffee at farm gate and differences found might be influenced by shading in traditional coffee systems.

Particularly they showed that agricultural production represents an important part of the environmental footprint of coffee, consequently, exploring crop shade management seems an accessible opportunity to reduce environmental impacts. Other promising means are to avoid off-fam contributions (input fabrication), for example, changing fertilization products from chemical fertilizers to compost. Additional opportunities exist making postharvest operations more efficient. Future work is needed to assess land use and land transformation impact categories and to complete the rest of life cycle after postharvest processes made on farm since food environment and consumption are also key drivers to reduce the environmental footprint of coffee.

Acknowledgments This work was funded by the FONTAGRO program (FTG/RF-14837-RG. Contract \#80), Agropolis Foundation (Contract \#1502-006), and the CGIAR Research Program on Climate Change, Agriculture and Food Security (CCAFS), which is carried out with support from CGIAR Fund donors and through bilateral funding agreements. For details, please visit https://ccafs.cgiar.org/donors. The views and 
opinions expressed in this document are those of the authors and do not necessarily reflect official positions of the sponsoring organizations. CCAFS is led by the International Center for Tropical Agriculture (CIAT). We acknowledge the stakeholders that participated in the process, especially the farmers involved in the project, for their time, knowledge, and patience and the Echohabitats Foundation that facilitated interactions with farmers. We also thank the editorial team and reviewers for their help to improve this work.

Open Access This article is distributed under the terms of the Creative Commons Attribution 4.0 International License (http:// creativecommons.org/licenses/by/4.0/), which permits unrestricted use, distribution, and reproduction in any medium, provided you give appropriate credit to the original author(s) and the source, provide a link to the Creative Commons license, and indicate if changes were made.

\section{References}

Acosta-Alba I, Chia E, Andrieu N (2019) The LCA4CSA framework: using life cycle assessment to strengthen environmental sustainability analysis of climate smart agriculture options at farm and crop system levels. Agric Syst 171:155-170

Arcila PJ, Farfan VF, Moreno B, Salazar G, Hincapié GE (2007) Sistemas de producción de café en Colombia, FNC, Cenicafé ed. Chinchiná, $310 \mathrm{pp}$

Arzoumanidis I, Salomone R, Petti L, Mondello G, Raggi A (2017) Is there a simplified LCA tool suitable for the Agri-food industry? An assessment of selected tools. J Clean Prod 149:406-425

Avelino J, Cristancho M, Georgiou S, Imbach P, Aguilar L, Bornemann G, Läderach P, Anzueto F, Hruska AJ, Morales C (2015) The coffee rust crises in Colombia and Central America (2008-2013): impacts, plausible causes and proposed solutions. Food Security 7:303-321

Bacon CM (2005) Confronting the coffee crisis: can fair trade, organic, and specialty coffees reduce small-scale farmer vulnerability in northern Nicaragua? World Dev 33(3):497-511

Bessou C, Basset-Mens C, Tran T, Benoist A (2013) LCA applied to perennial cropping systems: a review focused on the farm stage. Int J Life Cycle Assess 18:340-361

Bhattarai S, Alvarez S, Gary C, Rossing W, Tittonell P, Rapidel B (2017) Combining farm typology and yield gap analysis to identify major variables limiting yields in the highland coffee systems of llano Bonito, Costa Rica. Agric Ecosyst Environ 243:132-142

Buechley ER, Şekercioğlu ÇH, Atickem A, Gebremichael G, Ndungu JK, Mahamued BA, Beyene T, Mekonnen T, Lens L (2015) Importance of Ethiopian shade coffee farms for forest bird conservation. Spec Issue Ecol Conserv Avian Insectivores Rainfor Understory A Pan-Tropical Perspect 188:50-60

Bunn C, Läderach P, Ovalle Rivera O, Kirschke D (2015) A bitter cup: climate change profile of global production of Arabica and Robusta coffee. Clim Chang 129:89-101

Büsser S, Jungbluth N (2009) The role of flexible packaging in the life cycle of coffee and butter. Int J Life Cycle Assess 14:80-91

Cenicafé (2018) Caficultura en Colombia ahorra 850 millones de litros de agua al año. Accessed on November 20. URL: www. cafedecolombia.com/cci-fnc-es/index.php/comments/caficultura en_colombia_ahorra_850_millones_de_litros_de_agua_al_ano/

Coltro L, Mourad A, Oliveira P, Baddini J, Kletecke R (2006) Environmental profile of Brazilian green coffee. Int J Life Cycle Assess 11:16-21

Da Matta FM (2004) Ecophysiological constraints on the production of shaded and unshaded coffee: a review. Field Crop Res 86:99-114

De Beenhouwer M, Geeraert L, Mertens J, Van Geel M, Aerts R, Vanderhaegen K, Honnay O (2016) Biodiversity and carbon storage co-benefits of coffee agroforestry across a gradient of increasing management intensity in the SW Ethiopian highlands. Agric Ecosyst Environ 222:193-199

Echevarria JJ, Esguerra P, McAllister D, Robayo CF (2015) Informe de la misión de estudios para la competitividad de la caficultura en Colombia. Informe ejecutivo. 122 pp. (Spanish) URL: www. urosario.edu.co/Mision-Cafetera/Archivos/Resumen-Ejecutivoversion-definitiva/

EC-JRC (2011) European Commission, Joint Research Centre, institute for environment and sustainability. Characterisation factors of the ILCD. Recommended Life Cycle Assessment methods. Database and Supporting Information. First edit. Publications Office of the European Union, Luxembourg

European Environment Agency (EEA) (2013) EMEP/EEA air pollutant emission inventory guidebook 2013 - Technical guidance to prepare national emission inventories. European Environment Agency, Luxembourg, EEA Technical Report No. 12/2013. Available at www.eea.europa.eu

Faist Emmenegger M, Reinhard J, Zah R (2009) Sustainability quick check for biofuels - intermediate background report. With contributions from T. Ziep, R. Weichbrodt, prof. Dr. V. Wohlgemuth, FHTW Berlin and A. Roches, R. Freiermuth Knuchel, Dr. G. Gaillard, Agroscope Reckenholz-Tänikon. Dübendorf, Switzerland

FAO (2018) Food and agriculture Organization of the United Nations. FAOSTAT (database). (latest update: may 28, 2018) accessed (23 June 2018). In: URL www.fao.org/faostat/en/\#data/QC/visualize

Farfán-Valencia, F., 2005. Producción de café en un sistema intercalado con plátano dominico hárton con y sin fertilización química. Cenicafé 56, 269-280

Farfán-Valencia F (2014) Agroforestería y Sistemas Agroforestales con Café. Manizales, Caldas (Colombia). $342 \mathrm{pp}$

FNCC (2017) Comportamiento de la Industria Cafetera Colombiana 2017. Federación Nacional de Caféteros de Colombia. 64 pp. URL: https://www.federaciondecafeteros.org/static/files/Informe Industria_2017.pdf

Forero J (1996) Paysannerie, Économie Agraire et Système Alimentaire En Colombie. In: La Colombie à l'aube Du Troisième Millénaire. Ed IHEAL. Paris, Fr, pp 608

Freiermuth R (2006) Modell zur Berechnung der Schwermetallflüsse in der Landwirtschaftlichen Ökobilanz. Agroscope FAL Reckenholz, 42 p., Available at www.agroscope.admin.ch

Hanssen OJ, Rukke E-O, Saugen B, Kolstad J, Hafrom P, von Krogh L, Raadal HL, Rønning A, Wigum KS (2007) The environmental effectiveness of the beverage sector in Norway in a factor 10 perspective. Int J Life Cycle Assess 12:257-265

Hassard HA, Couch MH, Techa-erawan T, McLellan BC (2014) Product carbon footprint and energy analysis of alternative coffee products in Japan. J Clean Prod 73:310-321

Hergoualc'h K, Blanchart E, Skiba U, Hénault C, Harmand J-M (2012) Changes in carbon stock and greenhouse gas balance in a coffee (Coffea arabica) monoculture versus an agroforestry system with Inga densiflora, in Costa Rica. Agric Ecosyst Environ 148:102-110

Humbert S, Loerincik Y, Rossi V, Margni M, Jolliet O (2009) Life cycle assessment of spray dried soluble coffee and comparison with alternatives (drip filter and capsule espresso). J Clean Prod 17:13511358

ICO (2018) International coffee organization. Statistical production data. (last update: April 28, 2018) accessed (23 June 2018) URL: www. ico.org/prices/po-production.pdf

IDEAM (2018) Instituto de Hidrologia, Meteorologia y Estudios Ambientales. Valores medios y seguimiento de humedad del suelo por año. Ministerio URL: http://institucional.ideam.gov.co/jsp/ 1006. Accessed on: June 20th 2019. Adscrito al Ministerio de Ambiente y Desarrollo Sostenible de Colombia (Spanish)

IPCC (2006) 2006 IPCC Guidelines for National Greenhouse Gas Inventories. Volume 4: Agriculture, forestry and other land use. IGES, Kanagawa, Japan 
IPCC (2018) Global warming of $1.5^{\circ} \mathrm{C}$. an IPCC special report on the impacts of global warming of $1.5^{\circ} \mathrm{C}$ above pre-industrial levels and related global greenhouse gas emission pathways, in the context of strengthening the global response to the threat of climate change, sustainable development, and efforts to eradicate poverty [MassonDelmotte V, Zhai P, Pörtner H-O, Roberts D, Skea J, Shukla PR, Pirani a, Moufouma-Okia W, Péan C, Pidcock R, Connors S, Matthews JBR, Chen Y, Zhou X, Gomis MI, Lonnoy E, Maycock T, Tignor M, Waterfield T (eds.)] In Press

IPCC (Intergovernmental Panel on Climate Change) (2000) Special report on emissions scenarios. Geneva, Switzerland. Available at: www.ipcc.ch/ pdf/special-reports/spm/sres-en.pdf

Jarvis A, Ramírez-Villegas J, Tapasco J, Navarro C, Peterson C, ZapataCaldas E, Fisher M (2012) Are Climate Change Adaptation and Mitigation Options Eco-Efficient? Chapter 3. In: Hershey CH (ed). Eco-Efficiency: from vision to reality. Cali, Colombia: International Center for Tropical Agriculture (CIAT)

Jezeer RE, Verweij PA, Santos MJ, Boot RGA (2017) Shaded coffee and cocoa - double dividend for biodiversity and small-scale farmers. Ecol Econ 140:136-145

Jha S, Bacon CM, Philpott SM, Ernesto Méndez V, Läderach P, Rice RA (2014) Shade coffee: update on a disappearing refuge for biodiversity. Bioscience 64:416-428

Koch P, Salou T (2016) Agribalyse: Rapport Méthodologique - Version 1.3. ADEME, Angers, France. http://www.ademe.fr/sites/default/ files/assets/documents/agribalyse methodologie_v1_3.pdf

Koellner T, de Baan L, Beck T, Brandão M, Civit B, Margni M, i Canals LM, Saad R, de Souza DM, Müller-Wenk R (2013) UNEP-SETAC guideline on global land use impact assessment on biodiversity and ecosystem services in LCA. Int J Life Cycle Assess 18:1188-1202

Läderach P, Ramirez-Villegas J, Navarro-Racines C, Zelaya C, MartinezValle A, Jarvis A (2017) Climate change adaptation of coffee production in space and time. Clim Chang 141:47-62

Leblanc HA, McGraw RL, Nygren P, Le Roux C (2005) Neotropical legume tree Inga edulis forms $\mathrm{N}_{2}$-fixing symbiosis with fastgrowing Bradyrhizobium strains. Plant Soil 275(1-2):123-133

Leblanc HA, McGraw RL, Nygren P (2007) Dinitrogen-fixation by three neotropical agroforestry tree species under semi-controlled field conditions. Plant Soil 291(1-2):199-209

Lowder SK, Skoet J, Raney T (2016) The number, size, and distribution of farms, smallholder farms, and family farms worldwide. World Dev 87:16-29

Malézieux E, Crozat Y, Dupraz C, Laurans M, Makowski D, OzierLafontaine H, Rapidel B, De Tourdonnet S, Valantin-Morison M (2009) Mixing plant species in cropping systems: concepts, tools and models. A review. Agron Sustain Dev 29:43-69

Meylan L, Gary C. Allinne C, Ortiz J, Jackson L, Rapidel B (2017) Evaluating the effect of shade trees on provision of ecosystem services in intensively managed coffee plantations. Agric Ecosyst Environ 245:32-42

Morton JF (2007) The impact of climate change on smallholder and subsistence agriculture. Proc Natl Acad Sci 104:19680-19685

Nemecek T, Schnetzer J (2011) Methods of assessment of direct field emissions for LCIs of agricultural production systems data v3.0 (2012). ART - Agroscope Reckenholz-Tänikon Research Station ART, 34 pp, Zürich

Nemecek T, Dubois D, Huguenin-Elie O, Gaillard G (2011) Life cycle assessment of Swiss farming systems: I. integrated and organic farming. Agric Syst 104:217-232

Nemecek T, Bengoa X, Lansche J, Mouron P, Riedener E, Rossi V, Humbert S (2015) WFLCADB - food LCA database - methodological guidelines for the life cycle inventory of agricultural products, version 3.084

Nemecek T, Jeanneret P, Oberholzer HR, Schüpbach B, Roesch A, Alig M, Hofstetter P, Reidy B (2016) In: Höglind M, Bakken AK, Hovstad KA, Kallioniemi E, Riley H, Steinshamnm H, Østrem L (eds) Evaluating ecosystem services in the life cycle assessment of grassland-based dairy systems. NIBIO, Ás, Norway, pp 621-623

Noponen MRA, Edwards-Jones G, Haggar JP, Soto G, Attarzadeh N, Healey JR (2012) Greenhouse gas emissions in coffee grown with differing input levels under conventional and organic management. Agric Ecosyst Environ 151:6-15

Notarnicola B, Sala S, Anton A, McLaren SJ, Saouter E, Sonesson U (2017) The role of life cycle assessment in supporting sustainable Agri-food systems: a review of the challenges. J. Clean. Prod., towards eco-efficient agriculture and food systems: selected papers addressing the global challenges for food systems, including those presented at the conference "LCA for feeding the planet and energy for life" 6-8 October 2015, Stresa \& Milan Expo. Ita 140:399-409

Oliveros TCE, Ramírez GCA, Sanz UJR, Peñuela MAE, Pabón UJ (2013) Secado solar y secado mecánico del café. In: Manual del cafetero colombiano: Investigación y tecnología para la sostenibilidad de la caficultura. Chinchiná: FNC : CENICAFÉ, 2013. URL: https://www.cenicafe.org/es/index.php/cultivemos cafe/beneficio/P1

Ovalle-Rivera O, Läderach P, Bunn C, Obersteiner M, Schroth G (2015) Projected shifts in Coffea arabica suitability among major global producing regions due to climate change. PLoS One 10:e124155

Pelupessy W (2003) Environmental issues in the production of beverages: global coffee chain. In: Mattsson B, Sonesson U (eds) Environmentally friendly food processing. Woodhead Publishing Limited, Boca Raton, FL, pp 95-113

Prasuhn V (2006) Erfassung der PO4-Austräge für die Ökobilanzierung SALCA Phosphor. Agroscope Reckenholz - Tänikon ART, 20 p. Online at www.art.admin.ch/themen/00617/00744/index.html? lang=en

Puerta Quintero GI (1996) Evaluación de la calidad del café colombiano procesado por vía seca. Cenicafé 47(2):85-90. Technical review

Quiroz M, Céspedes C (2019) Bokashi as an amendment and source of nitrogen in sustainable agricultural systems: a review. J Soil Sci Plant Nutr 19:237-248

Ramirez-Villegas J, Salazar M, Jarvis A, Navarro-Racines C (2012) A way forward on adaptation to climate change in Colombian agriculture: perspectives towards 2050. Clim Chang 115:611-628

Ruben R, Menenes N, Ponsioen T, Sfez P (2018) Análisis Integral de la cadena de valor del café en Honduras. Informe por la Unión Europea, DG-DEVCO. Value chain analysis for development project (VCA4D CTR 2016/375-804), 98 p. Available online at http:// edepot.wur.nl/450336

Sanz Uribe J, Oliveros Tascon C, Ramirez Gomez C, Lopez Posada U, Velasquez H (2011) Control de los flujos de café y agua en el módulo Becolsub. Cenicafé. Avances Técnicos 405. ISSN 0120 0178. URL: http://biblioteca.cenicafe.org/bitstream/10778/40/1/ avt0405.pdf

Sauvadet M, Van den Meersche K, Allinne C, Gay F, de Melo Virginio Filho E, Chauvat M, Becquer T, Tixier P., Harmand JM (2019) Shade trees have higher impact on soil nutrient availability and foodweb in organic than conventional coffee agroforestry. Sci Total Environ 649:1065-1074

Soto-Pinto L, Perfecto I, Castillo-Hernandez J, Caballero-Nieto J (2000) Shade effect on coffee production at the northern Tzeltal zone of the state of Chiapas, Mexico. Agric Ecosyst Environ 80:61-69

Szott LT, Kass DCL (1993) Fertilizers in agroforestry systems. Agrofor Syst 23:157-176

Tock JY, Lai CL, Lee KT, Tan KT, Bhatia S (2010) Plantain biomass as potential renewable energy resource: a Malaysian case study. Renew Sust Energ Rev 14(2):798-805

van Rikxoort H, Schroth G, Läderach P, Rodríguez-Sánchez B (2014) Carbon footprints and carbon stocks reveal climate-friendly coffee production. Agron Sustain Dev 34:887-897

Villarreyna Acuña R (2016) Efecto de los árboles de sombra sobre el rendimiento de los cafetos basado en perfiles de daño. Informe 
proyecto Cascada 34 p. https://www.researchgate.net/profile/ Rogelio_Villarreyna-Acuna/publication/312190528_Efecto_de_ los_arboles_de_sombra_sobre_el_rendimiento_de_tos_cafetos basado_en_perfiles_de_dano/links/5875182c08aebf17d3b3f33f/ Efecto-de-los-arboles-de-sombra-sobre-el-rendimiento-de-loscafetos-basado-en-perfiles-de-dano.pdf

Waller JM, Bigger M, Hillocks RJ (2007) World coffee production. In: Coffee pests, diseases and their management. Egham, Surrey, UK, pp 17-33. https://doi.org/10.1079/9781845931292.0000

Wang N, Jassogne L, van Asten PJA, Mukasa D, Wanyama I, Kagezi G, Giller KE (2015) Evaluating coffee yield gaps and important biotic, abiotic, and management factors limiting coffee production in Uganda. Eur J Agron 63:1-11
Wernet G, Bauer C, Steubing B, Reinhard J, Moreno-Ruiz E, Weidema B (2016) The ecoinvent database version 3 (part I): overview and methodology. Int J Life Cycle Assess 21:1218-1230

WFLDB (2014) Nemecek T, Bengoa X, Lansche J, Mouron P, Rossi V, Humbert S. Methodological Guidelines for the Life Cycle Inventory of Agricultural Products. Version 2.0, July 2014. World Food LCA Database (WFLDB) Quantis and Agroscope, Lausanne and Zurich, Switzerland

Publisher's note Springer Nature remains neutral with regard to jurisdictional claims in published maps and institutional affiliations. 